DOI: $10.5578 / \mathrm{fmbd} .34251$

Araştırma Makalesi / Research Article

\title{
Identification Of River Retention Coefficients for Nutrients In Melen Watershed
}

\author{
Muhammed Ernur Akıner ${ }^{1}$ \\ ${ }^{1}$ Akdeniz Üniversitesi, Teknik Bilimler Meslek Yüksekokulu, 07058, Konyaaltı, Antalya. \\ ernurakiner@akdeniz.edu.tr
}

Geliş Tarihi: 28.03.2016 ; Kabul Tarihi: 09.11.2016

Keywords Melen Watershed; Nutrient; Water Quality; GIS; DEM; River Retention Coefficient.

\begin{abstract}
Melen Watershed is the most recent and the leading drinking water source of Istanbul. According to The Ministry of Forest and Water Works of Turkey, regarding the pollution status, Melen River Basin should be primarily dealt with. Nutrient pollution such as nitrogen $(N)$ and phosphorus $(P)$ can cause water quality degradation in rivers, which are used as a source of drinking water. Buyuk Melen and Kucuk Melen rivers are existed on Melen Watershed. Water supplied from Buyuk Melen River is tranferred to Omerli Dam and supplies important percent of the water demand of the Istanbul. Hence, it is crucial to observe the water quality of the supplied water in Melen Watershed. Certain percent of the nutrients that cause the organic pollution are retained through the river route. River retention coefficient is the percent that reflects how many percent of the nutrients are retained during the river flow. River retention coefficient for the rivers on the Melen Watershed was calculated according to the several factors mentioned in this study. For this purpose geographical information systems (GIS) were also dealt with and digital elevation model (DEM) was prepared using raster images scaled 1/25000. This study is aimed to be an important precedent for other basins that are determined as in priority in terms of pollution by The Ministry of Forest and Water Works of Turkey.
\end{abstract}

\section{Melen Havzasında Besin Maddeleri için Nehir Alıkonum Katsayısının Tespiti}

\section{Anahtar kelimeler}

Melen Havzası; Besin

Maddesi; Su Kalitesi;

CBS; SYM; Nehir

Alıkonum Katsayısı.

\begin{abstract}
Özet
Melen Havzası İstanbul'un en yeni ve önemli içme suyu kaynağıdır. T.C. Orman ve Su İşleri Bakanlığı tarafından Melen Havzası kirlilik açısından öncelikli olarak ele alınacak havzalar içinde 1. sırada ilan edilmiştir. Azot (N), fosfor (P) gibi besin maddesi kirliliği, içme suyu kaynağı olarak kullanılan akarsularda su kalitesinin düşmesine neden olmaktadır. Melen Havzası üzerinde Büyük Melen ve Küçük Melen nehirleri bulunmaktadır. Büyük Melen Nehri suyu İstanbul'daki Ömerli Baraj Gölü’ne aktarılmakta ve İstanbul'un su ihtiyacını önemli ölçüde karşılamaktadır. Bu nedenle, Melen Havzası'ndan alınan suyun kalitesinin takibi önem arz etmektedir. Organik kirliliğe neden olan besin maddelerinin belirli bir yüzdesi nehir boyunca tutulur. Nehir alıkonum katsayısı, besin maddelerinin hangi oranda nehir akışı boyunca tutulduğunu gösteren yüzdedir. Bu çalışma da belirtilen birçok faktöre bağlı olarak Melen Havzası üzerindeki nehirler için nehir alıkonum katsayısı tespit edilmiştir. Bu amaçla coğrafi bilgi sistemlerinden (CBS) faydalanılmış ve 1/25000 ölçekli memleket haritalarından da yararlanılarak Melen Havzası için sayısal yükseklik modeli (SYM) oluşturulmuştur. Bu çalışma T.C. Orman ve Su İşleri Bakanlığı'nın kirlenme açısından öncelik sırasına koyduğu diğer havzalar için de önemli bir örnek teşkil edecektir.
\end{abstract}

(c) Afyon Kocatepe Üniversitesi

\section{Introduction}

Though they occur naturally in water, soil and air in various forms, high contents of nutrients in water such as nitrates $(\mathrm{N})$ and phosphorus $(\mathrm{P})$ are the major issues in terms of water quality, which are generally believed to be caused by nonpoint source pollution since it is mainly the result of agricultural activities and not easy to specify the location of the exact source (Niraula et al., 2013). The total quantity of nutrients discharged into surface 
waters in a river basin is normally larger than the nutrient load at the river mouth. This discrepancy can be explained by the process of nutrient retention (Bere, 2007). Retention in watersheds is a function of many biogeochemical parameters and hydromorphological characteristics of rivers, lakes, etc. In general; nitrogen retention is more influenced by biological processes as denitrification, whereas phosphorus retention is more influenced by physico-chemical processes, such as sedimentation and sorption/desorption reactions in sediments (Behrendt and Opitz, 2000). One of the most important functions of headwaters is their ability to filter pollution from stormwater runoff. This reduces concentrations of nutrients, sediment, and toxic pollutants from surface runoff. Not only are toxic pollutants removed in the root zones and sediment trapped in the leaves, but the biological and physical action of riffles and pools also polish the water quality as it runs on the surface (Peterson et al., 2001). An understanding of the nutrient retention process is important to prevent overloading the river, lake system and the resultant eutrophication (Bere, 2007). Peterson et al. (2001) examined the nitrogen removal efficiencies of headwater streams from all over the United States. They found that the smaller the stream (lower the order), the higher the efficiency for removal of nitrogen. This is because the water is in greater contact with various biofilm surfaces in smaller streams. On average, dissolved nitrogen (dissolved inorganic nitrogen; both $\mathrm{NH}_{4}{ }^{+}$and $\mathrm{NO}_{3}{ }^{-}$) is removed at a rate of $64 \%$ per kilometer of a stream. It was demonstrated that the use of export coefficients estimated for other regions may lead to wrong conclusions about the impact of different diffuse sources on the water body status. Land use-land cover maps had a significant effect on both runoff and sediment yield prediction (Di Luzio, 2005). Soil classification maps showed a limited influence on model results. The primary GIS data that must be provided are: (1) the digital elevation model (DEM); (2) the land use-land cover map; and (3) the soil map. The watershed and stream network delineation and the definition of several geomorphological parameters are calculated from the digital elevation model.

\section{Materials and Methods}

Pertaining to their integrative capabilities, geographic information systems (GIS) are also powerful and essential tools for watershed scale hydrologic analysis and modelling. GIS allows the effective and efficient integration of spatial and non-spatial data for model inputs as well as the spatial visualization of outputs.

\subsection{Watershed delineation}

The watershed is delineated into discrete subwatersheds for enabling the modeling to represent the spatial heterogeneity in the catchment. The delineation of the Melen Watershed was carried out based on a Digital Elevation Model (DEM) created in $10 \mathrm{~m} . \times 10 \mathrm{~m}$. resolution by both digitizing topographical map sheets and modifiying the available vector maps. Created DEM was imported to Arcview grid format with proper projection (UTM - Zone $36 \mathrm{~N}$ - WGS84 Datum). Size and number of the subwatersheds are determined according to the streams. While a larger number of subwatersheds provides beter spatial heterogeneity, it causes an increased amount of input data preparation and might also result in too detailed unnecessary spatial variation. Therefore, a careful setting of threshold is necessary for representing the optimum spatial heterogeneity in the catchment. The watershed was discretized into 10 subwatersheds based on the delineated stream network (See Figure 1). While doing this, number of measuring stations and their locations were also considered. 


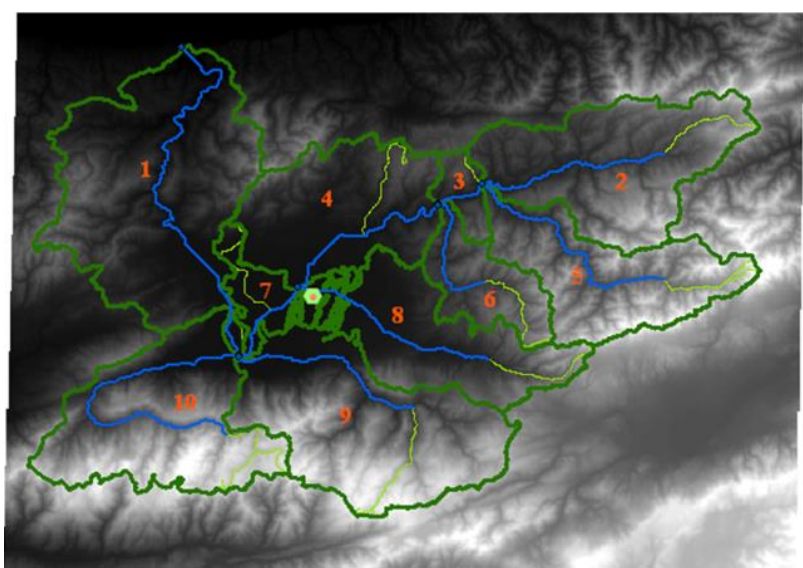

Figure 1. Subwatersheds, rivers, and Duzce Meteorological Station of the Melen Watershed.

\subsection{The data used}

Topography of the Melen Watershed was defined by a DEM that describes the elevation of any point in a given area at a specific spatial resolution. 40 vector maps were modified using image topographic maps in scale 1/25000 (DSI, 2010) (See Figure 2 and 3 ).

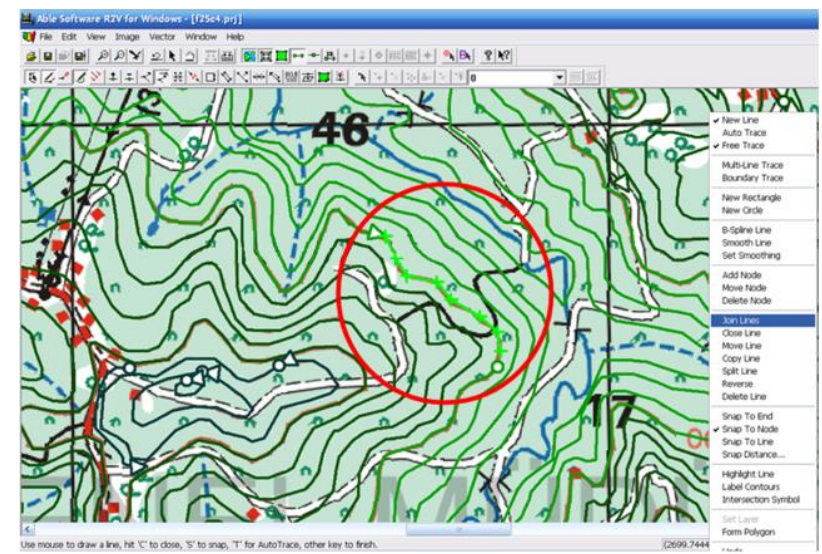

Figure 2. Vectorization of image topographic maps at scale $1 / 25000$.

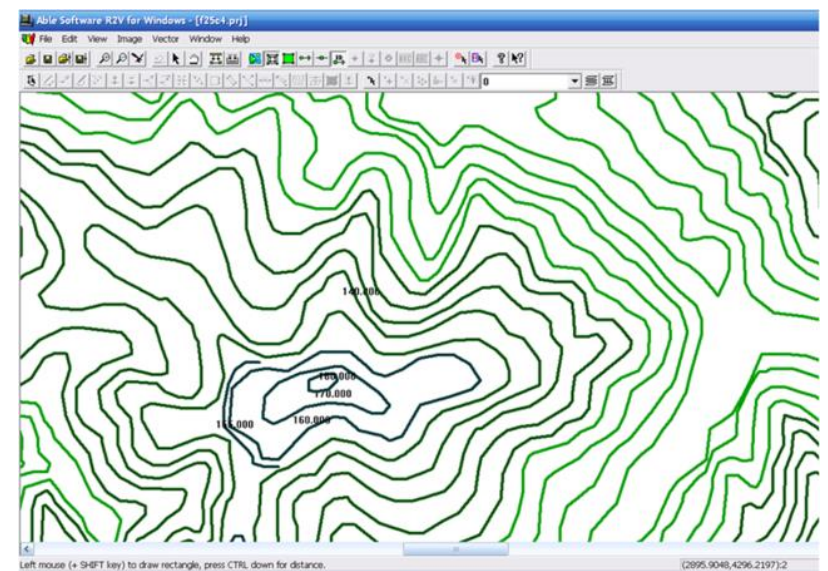

Figure 3. Assigning elevations to contour lines.
All modified vector maps were merged and a $10 \mathrm{~m}$ by $10 \mathrm{~m}$ resolution DEM (See Figure 4) was prepared. The DEM was used to delineate the watershed and analyzing the drainage patterns. Subbasin parameters such as slope gradient, slope length of the terrain, and the stream network characteristics such as channel slope, length, and width were derived from the DEM.

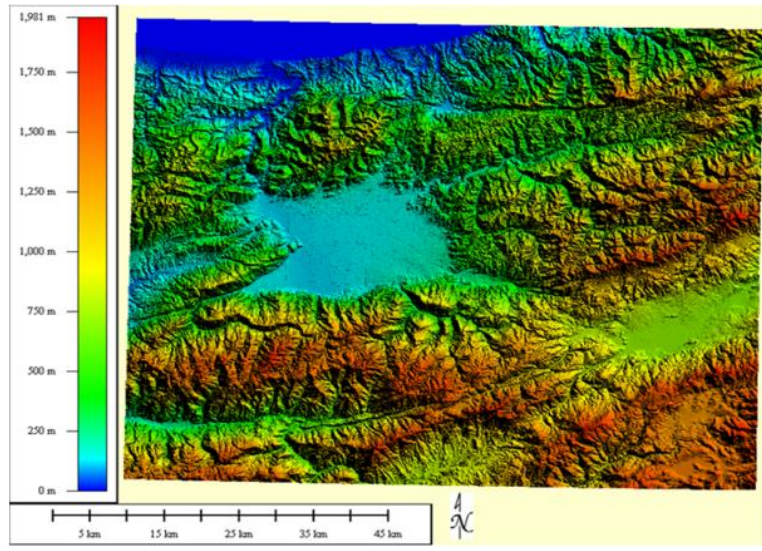

Figure 4. 10 meters grid spacing DEM generated from contour lines.

Meteorological data was obtained from both Turkish and American sources (TMS, 2010; NOAA, 2010) for Duzce and Bolu Meteorology Stations. Unknown parameters and missing data were simulated using the closest Bolu Meteorological Station. Precipitation is the driving force behind all hydrologic processes occurring in a watershed. It is characterized by spatial and temporal variability. Representation of this variability in models can be expected to improve short-term and long-term simulation results (Jayakrishnan, 2005). Monthly observed data of Flow, $\mathrm{NO}_{3}^{-}, \mathrm{NH}_{3}, \mathrm{NO}_{2}^{-}, \mathrm{CBOD}, \mathrm{DO}$, Temp, TN, TKN, Total $\mathrm{P}$, between 1995 and 2007 were gathered from State Hydraulic Works of Turkey (DSI, 2011). Sampling points and their coordinates are shown in Figure 5.

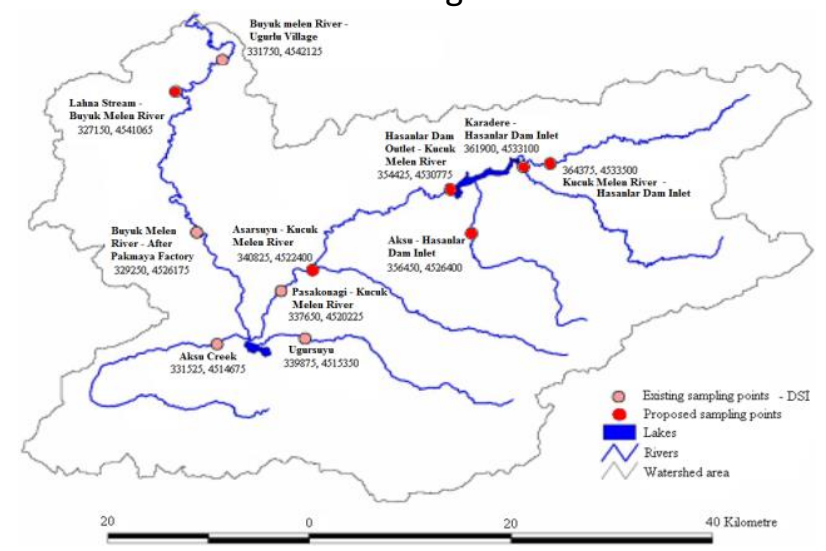

Figure 5. Sampling point coordinates in WGS84 Datum UTM coordinate system $36 \mathrm{~N}$. 


\subsection{Nutrient retention phenomenon}

Retention of nutrients was also taken into consideration in many studies while calculating the load at the outlet of the watersheds. In summary, most phosphorus retention in fresh water systems is due to sedimentation and adsorption to sediment (Bukaveckas and Isenberg, 2013; Gonzales-Sanchis, 2015; Shilla, 2014). By contrast, the major retention mechanism for nitrogen in fresh waters is denitrification. Denitrification is strongly dependent on temperature and therefore, high denitrification rates occur during summer (Song et al., 2014). During the wet months, some sections of the river acted as sources of nutrients instead of sinks resulting in negative nutrient retention values. This suggests that previously retained nitrogen may have been re-suspended during storms or extra nutrients were coming from other sources in the sub-catchments (Bere, 2007).

It is necessary to select a river retention model, which gives monthly reliable predictions. Hence, the retention model of de Klein and Koelmans (2011) is based on 112 rivers; TN and TP retention models of de Klein and Koelmans (2011) is considered as the most reliable models for our research area. The retention and loss of nutrients in river systems specified using the approach of de Klein and Koelmans (2011). Monthly retention of nitrogen can be estimated from surface water area specific runoff as seen in Equation 1. Monthly phosphorus retention can be estimated from surface water area specific runoff and temperature as seen in Equation 2 (de Klein and Koelmans, 2011).

$$
R_{i}^{N}=0.0246\left(\frac{Q_{i}}{S W}\right)^{-0.57}
$$

where $Q_{i}$ is the average (monthly) discharge $\left(\mathrm{m}^{3} \mathrm{~s}^{-1}\right)$; SW is the total area of surface water in the catchment (ha); $\mathrm{Ri}$ is the retention fraction (-); and $\mathrm{i}$ the index for month (-).

$$
R_{i}^{P}=0.253\left(\frac{Q_{i}}{S W}\right)^{-0.20} \times 1.01^{\left(T_{i}-20\right)}
$$

where $\mathrm{T}$ is the temperature. In their study, de Klein and Koelmans (2011) noticed that the correlation between measured and calculated values for the training set was high $\left(\mathrm{N}: \mathrm{r}^{2}=0.93 ; \mathrm{p}<0.001\right.$ and $\mathrm{P}$ : $\left.r^{2}=0.81 ; p<0.001\right)$

For the calculation of $Q$ values, a relation between precipitation values and discharge $(Q)$ values were analyzed using the Bayesian approach.

\section{Findings}

Within this study, best approach for the estimation of nutrient retention will be pointed out with the help of the limited number of observed retentions from selected river section of Buyuk Melen River. Since models from literature only consider TP and TN retention, it is assumed that the percent retention estimated by these models will also be the same for all inorganic and organic forms or compounds.

Well known models (Behrendt and Opitz, 2000; de Klein and Koelmans, 2011; Fakioglu and Pulatsu, 2005) were tested for retention estimation in Buyuk Melen River. Kucuk Melen River, Ugursuyu, and Aksu Creek are other rivers linked to Buyuk Melen River. This point can be called as the joint of Kucuk Melen and Buyuk Melen Rivers. River section between this joint point and Buyuk Melen River Pakmaya Factory is the only feasible location for the observation of nutrient retention (see Figure 6). Therefore, this section is selected for the observations. Although there is a limited number of observed data available, it was enough to see the best reliable empirical nutrient retention model. Water surface area of selected river section is approximately 45 ha $\left(0.45 \mathrm{~km}^{2}\right)$, and the drainage area of this section is around $160 \mathrm{~km}^{2}$.

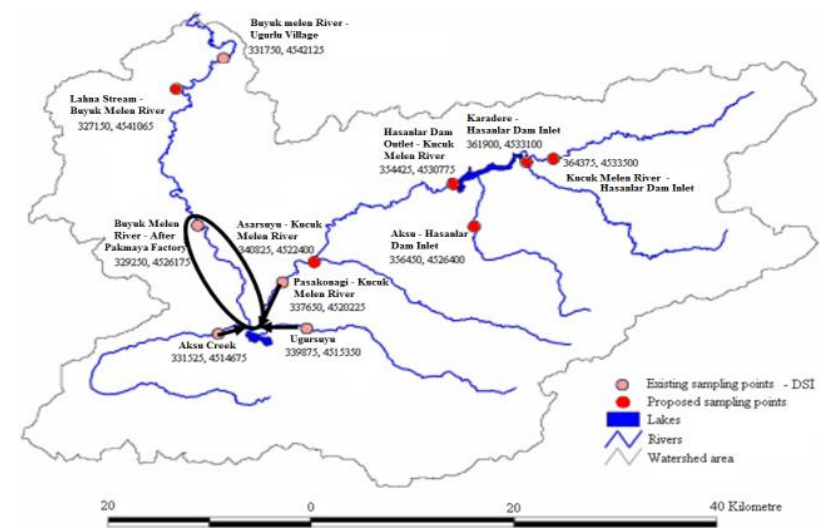

Figure 6. Selected river section for the calculation of the retention coefficients. 
A few observation data of TP are available for Kucuk Melen River - Pasakonagi, Ugursuyu, Aksu Creek points. Sum of this TP data was considered as the input load for the selected river section. In other words, this load is considered as the TP load at the joint of Kucuk Melen and Buyuk Melen Rivers. According to mass balance approach, subtraction of the load at the joint of Kucuk Melen and Buyuk Melen Rivers (inflow) from the load at Buyuk Melen River - Pakmaya Factory point (outflow) gives the observed TP retention. Then percent retention of TP load is calculated by dividing this value by the input TP load and multiplying by hundred. Same procedure was applied for the Total Nitrogen (TN) also.

Bayesian analysis was conducted using AMOS software (Arbuckle, 2009) and missing discharge (Q) values for the measuring point at the outlet (B. Melen River Ugurlu Village) were specified. Then using the statistical relation between this measuring point and the others, all missing discharge (Q) values were estimated (see Figure 7). Since we need temperature values for each month in order to calculate phosphorus retention in rivers at each subwatershed, missing temperature values were estimated using statistical techniques. There is a significant correlation between the observed temperature values of each subwatershed and subwatershed 1 (sampling point at the outlet). Moreover, the highest number of observed temperature values exists for subwatersed 1. First of all, the trend of the temperature values of the measuring point at the outlet (B. Melen River Ugurlu Village) or subwatershed 1 for the years between 1995 and 2011 was specified as a sinusoidal function (see Figure 8 ). Then using this function, missing temperature values for the measuring point at the outlet (B. Melen River Ugurlu Village) were specified.

Finally, using the statistical relation between this measuring point and the others (see Figure 9), all missing temperature values were estimated. Temperature relation between B. Melen River Ugurlu Village and all other sampling points are summarized in Table 1.

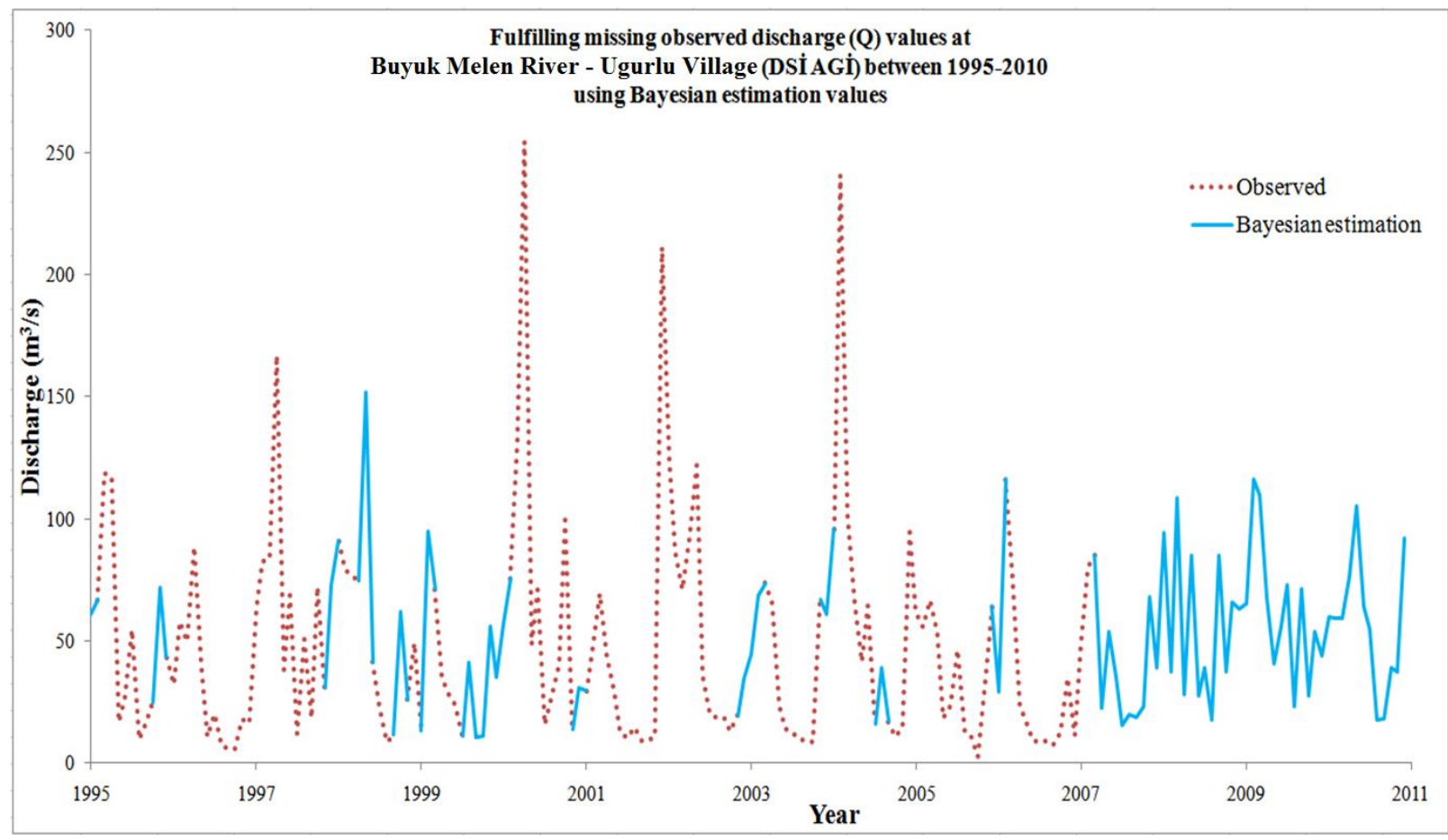

Figure 7. Fulfilling missing observed discharge (Q) values at B. Melen Çayı Uğurlu Köyü between 1995-2010 using Bayesian estimation values. 


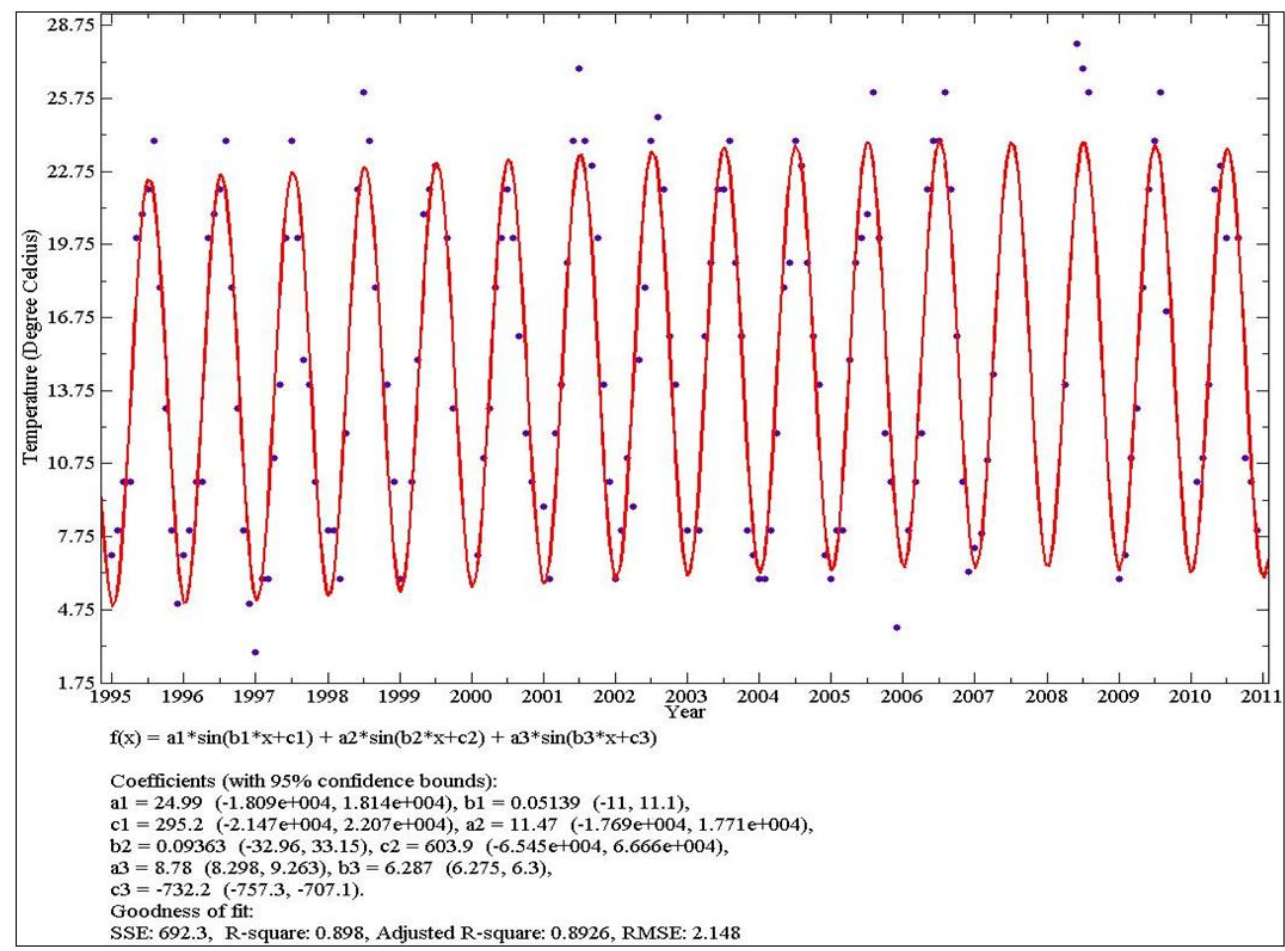

Figure 8. The trend of the temperature values of the measuring point at the outlet (B. Melen Çayı Uğurlu Köyü).

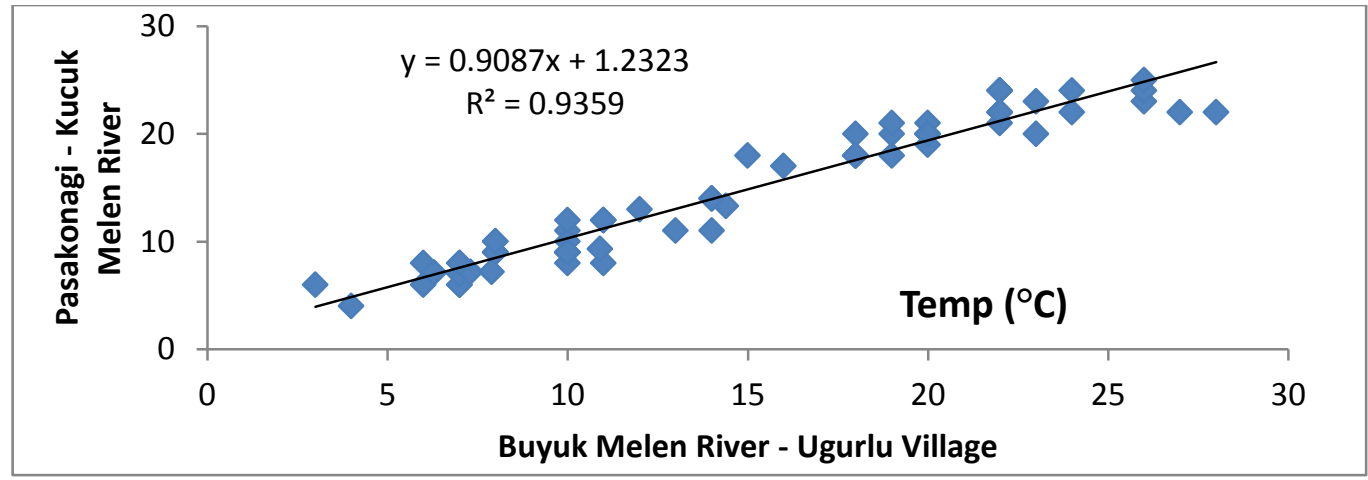

Figure 9. Temperature relation between measuring points K. Melen Çayı Paşakonağı and B. Melen Çayı Uğurlu Köyü.

Table 1. Temperature relation between B. Melen Çayı Uğurlu Köyü and all other sampling points.

\begin{tabular}{|c|c|c|c|}
\hline $\mathbf{x}$ & $\mathbf{y}$ & Equation & $\mathbf{R}^{2}$ \\
\hline \multirow{11}{*}{ 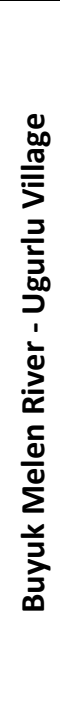 } & Pasakonagi - Kucuk Melen River & $y=0.9087 x+1.2323$ & 0.9359 \\
\hline & Kucuk Melen River - Hasanlar Dam Inlet & $y=1.0647 x-2.9742$ & 0.9412 \\
\hline & Kucuk Melen River - Hasanlar Dam Outlet & $y=0.8086 x+0.2543$ & 0.8356 \\
\hline & Asarsuyu - Kucuk Melen River & $y=0.7057 x+3.7053$ & 0.8939 \\
\hline & Karadere - Hasanlar Dam Inlet & $y=0.8812 x-1.75$ & 0.9351 \\
\hline & Aksu - Hasanlar Dam Inlet & $y=0.8686 x+0.0982$ & 0.9365 \\
\hline & Buyuk Melen River - After Pakmaya & 955 & 0.9207 \\
\hline & Factory & & \\
\hline & Ugursuyu & $y=1.0523 x-0.8871$ & 0.8964 \\
\hline & Aksu Creek & $y=0.8961 x+0.4644$ & 0.9086 \\
\hline & Lahna Stream - Buyuk Melen River & $y=0.9278 x+1.6118$ & 0.9584 \\
\hline
\end{tabular}




\section{Results and Discussions}

It is crucial to define the percent retention of nutrients in a watershed especially if it is the source for a drinking water of the mega city like istanbul. It is well known that the treatment cost is directly proportional to the quality of the source water. In this research the Melen Watershed located in Western Black Sea region of Turkey was selected as a research area. River retention coefficients for the Total Phosphorus (TP) and the Total Nitrogen (TN) were determined according to the basin characteristics. In Figures 10 and 11 river retention values in percentage for the Total Phosohorus (TP) and the Total Nitrogen (TN) are depicted. Calculations were conducted regarding the empirical model developed by de Klein and Koelmans (2011). Annual average monthly percent Total Nitrogen (TN) and Total Phosphorus (TP) retention for all subwatersheds is summarized in Tables 2 and 3.

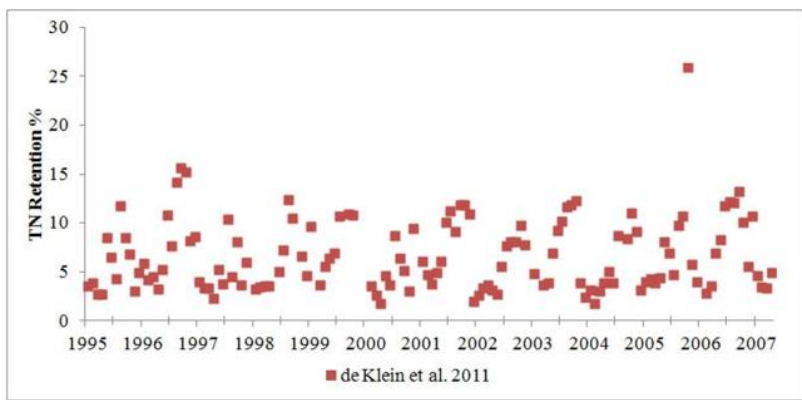

Figure 10. Percent TP retention estimations by empirical models (de Klein and Koelmans, 2011) in selected river section.

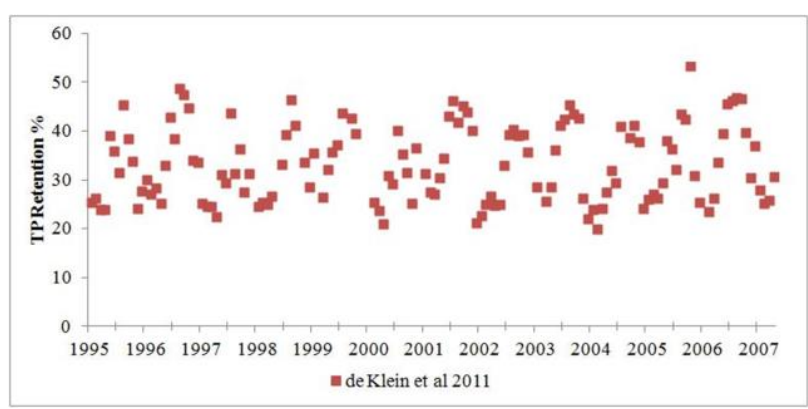

Figure 11. Percent TN retention estimations by empirical models (de Klein and Koelmans, 2011) in selected river section.

Table 2. Annual average monthly percent nitrogen retention for all subwatersheds

\begin{tabular}{ccccccccccc}
\hline & \multicolumn{10}{c}{ Subwatershed } \\
\hline Year & 1 & 2 & 3 & 4 & 5 & 6 & 7 & 8 & 9 & 10 \\
1995 & 5.34 & 28.75 & 21.15 & 17.24 & 23.04 & 45.44 & 4.75 & 23.70 & 32.07 & 18.20 \\
1996 & 8.03 & 33.59 & 26.33 & 21.45 & 29.64 & 59.81 & 8.47 & 30.56 & 47.99 & 27.26 \\
1997 & 4.56 & 23.03 & 16.15 & 13.16 & 20.56 & 40.22 & 3.59 & 19.21 & 26.56 & 15.47 \\
1998 & 5.20 & 29.24 & 17.24 & 14.04 & 22.26 & 43.89 & 4.87 & 21.20 & 33.83 & 19.71 \\
1999 & 6.44 & 36.44 & 29.03 & 23.65 & 26.50 & 52.73 & 5.77 & 33.16 & 45.40 & 22.21 \\
2000 & 4.62 & 23.23 & 17.62 & 14.38 & 20.75 & 40.65 & 3.81 & 16.93 & 33.72 & 16.38 \\
2001 & 7.21 & 44.62 & 28.25 & 23.06 & 28.14 & 56.47 & 6.58 & 43.95 & 53.83 & 25.21 \\
2002 & 5.30 & 27.39 & 25.37 & 20.67 & 23.06 & 45.47 & 4.48 & 20.77 & 38.31 & 18.91 \\
2003 & 6.72 & 41.58 & 25.48 & 20.51 & 26.67 & 53.31 & 6.01 & 38.65 & 50.35 & 24.17 \\
2004 & 5.19 & 27.90 & 21.96 & 18.02 & 22.26 & 43.94 & 4.30 & 21.35 & 41.64 & 18.75 \\
2005 & 7.18 & 34.72 & 25.30 & 20.62 & 26.29 & 50.94 & 5.72 & 20.84 & 40.57 & 23.37 \\
2006 & 8.04 & 46.58 & 30.72 & 25.03 & 30.76 & 61.10 & 8.17 & 42.36 & 47.38 & 29.66 \\
2007 & 5.41 & 27.50 & 24.08 & 19.62 & 23.11 & 44.83 & 4.41 & 19.60 & 38.08 & 19.30 \\
2008 & 4.49 & 21.71 & 14.61 & 11.90 & 20.72 & 40.40 & 3.53 & 14.29 & 27.90 & 16.04 \\
2009 & 4.12 & 19.52 & 11.88 & 9.68 & 19.49 & 37.83 & 3.18 & 12.40 & 24.29 & 14.81 \\
2010 & 4.47 & 21.73 & 15.46 & 12.59 & 20.59 & 40.15 & 3.53 & 14.54 & 28.33 & 15.96 \\
\hline
\end{tabular}


Table 3. Annual average monthly percent phosphorus retention for all subwatersheds

\begin{tabular}{ccccccccccc}
\hline & \multicolumn{1}{c}{ Subwatershed } \\
\hline Year & 1 & 2 & 3 & 4 & 5 & 6 & 7 & 8 & 9 & 10 \\
1995 & 30.82 & 53.72 & 46.73 & 43.49 & 50.12 & 64.58 & 29.03 & 48.83 & 54.99 & 46.46 \\
1996 & 35.31 & 59.33 & 51.59 & 48.01 & 54.73 & 71.05 & 34.65 & 53.43 & 65.18 & 53.86 \\
1997 & 28.84 & 49.35 & 42.19 & 39.26 & 47.68 & 61.28 & 26.53 & 42.27 & 53.47 & 44.17 \\
1998 & 30.77 & 54.00 & 44.36 & 41.28 & 50.01 & 64.40 & 29.61 & 45.48 & 58.72 & 48.23 \\
1999 & 33.42 & 59.31 & 52.37 & 48.74 & 53.40 & 69.01 & 31.78 & 50.70 & 64.74 & 51.25 \\
2000 & 29.13 & 49.82 & 43.28 & 40.44 & 48.06 & 61.78 & 26.89 & 44.21 & 56.93 & 45.08 \\
2001 & 35.20 & 64.41 & 53.58 & 49.72 & 55.13 & 71.44 & 33.56 & 58.56 & 68.13 & 53.97 \\
2002 & 31.08 & 53.79 & 49.27 & 45.85 & 50.56 & 65.13 & 29.08 & 48.24 & 61.47 & 47.98 \\
2003 & 33.60 & 61.05 & 50.17 & 46.68 & 53.19 & 68.82 & 32.07 & 58.15 & 64.57 & 52.57 \\
2004 & 30.42 & 52.96 & 49.55 & 46.11 & 49.49 & 63.75 & 28.06 & 46.88 & 61.73 & 47.46 \\
2005 & 33.47 & 57.45 & 49.78 & 46.32 & 52.58 & 68.01 & 31.21 & 48.64 & 62.57 & 50.61 \\
2006 & 36.33 & 67.97 & 55.65 & 51.79 & 56.48 & 73.02 & 35.84 & 60.34 & 71.13 & 56.66 \\
2007 & 32.11 & 55.42 & 49.76 & 46.31 & 51.54 & 66.13 & 29.57 & 49.25 & 63.00 & 49.64 \\
2008 & 30.28 & 51.89 & 43.59 & 40.57 & 50.28 & 64.36 & 27.32 & 44.37 & 56.39 & 46.32 \\
2009 & 29.02 & 49.02 & 40.46 & 37.66 & 48.33 & 61.97 & 26.36 & 41.76 & 53.85 & 44.77 \\
2010 & 29.50 & 50.16 & 42.89 & 39.91 & 48.86 & 62.74 & 26.91 & 43.67 & 55.27 & 45.23 \\
\hline
\end{tabular}

\section{Conclusions}

Results show that there is a considerable amount of retention for both TP and TN values through the river network in the Melen Watershed.

Results of this study can be a significant example for the researches that are being conducted in other watersheds.

It can also help decision makers for creating sustainable way of treatment instead of using highly expensive conventional treatment processes.

\section{References}

Arbuckle, J. L., 2009. AMOS 18 User's Guide, AMOS Development Corporation, 636.

Behrendt, H., and Opitz, D., 2000. Retention of Nutrientsin River Systems: Dependence on Specific Runoff and Hydraulic Load. Hydrobiologia, 410, 111-122.

Bere, T., 2007. The Assessment of Nutrient Loading and Retention in the Upper Segment of the Chinyika River, Harare: Implications for Eutrophication Control. Water SA, 33(2), 279284.
Bukaveckas, P.A. and Isenberg, W.N., 2013. Loading, transformation, and retention of nitrogen and phosphorus in the tidal freshwater James River(Virginia). Estuaries and coasts, 36(6), 1219-1236.

de Klein, J. J. M., and Koelmans, A. A., 2011. Quantifying Seasonal Export and Retention of Nutrients in West European Lowland Rivers at Catchment Scale. Hydrological Processes, 25(13), 2102-2111.

Di Luzio, M., Arnold, J. G. and Srinivasan, R., 2005. Effect of GIS Data Quality on Small Watershed Stream Flowand Sediment Simulations. Hydrological Processes, 19(3), 629-650.

DSI (State Hydraulic Works), 2011. 1995-2010 Stream Pollution Parameters Measurements in the Melen Watershed, Ankara, Turkey, (Unpublished report).

DSI (State Hydraulic Works), 2010. 1/25000 Scale Topographic Maps and Vector Maps of the Melen Watershed Area, Ankara, Turkey.

Fakioglu, O., and Pulatsu, S., 2005. Mogan Gölü’nde (Ankara) Bazı Restorasyon Önlemleri Sonrası Dış Kaynaklı Fosfor Yükünün Belirlenmesi [In Turkish]. Yüzüncü Yıl Üniv. Ziraat Fakültesi Dergisi, 15(1), 63-69. 
González-Sanchis, M., Murillo, J., Cabezas, A., Vermaat, J.E., Comín, F.A. and García-Navarro, P., 2015. Modelling sediment deposition and phosphorus retention in a river floodplain. HydrologicalProcesses, 29(3), 384-394.

Jayakrishnan, R., Srinivasan, R., Santhi, C. and Arnold, J.G., 2005. Advances in the Application of the SWAT Model For Water Resources Management. Hydrological Processes, 19(3), 749-762.

Niraula, R., Kalin, L., Srivastava, P. and Anderson, C.J., 2013. Identifying critical source areas of non point source pollution with SWAT and GWLF. Ecologicalmodelling, 268, 123-133.

NOAA (National Oceanic and Atmospheric Administration), 2010. Düzce and Bolu Meteorological Data, http://www.noaa.gov/.

Peterson, B. J., Wollheim, W. M., Mulholland, P. J.,Webster, J. R., Meyer, J. L., Tank, J. L., Marti, E.,Bowden, W. B., Valett, H. M., Hershey, A. E.,McDowell, W. H., Dodds, W. K., Hamilton, S. K.,Gregory, S., and Morrall, D. D., 2001. Control ofNitrogen Export from Watersheds by Headwater Streams. Science, 292, 86-90.

Shilla, D., 2014. Fluxes and retention of nutrients and organic carbon in Manko estuary, Okinawa, Japan: influence of river discharge variations. Advances in Oceanography and Limnology, 5(2), 141-163.

Song, K., Hernandez, M.E., Batson, J.A. and Mitsch, W.J., 2014. Long-term denitrification rates in created riverine wetlands and their relationship with environmental factors. Ecological Engineering, 72, 40-46.

TMS (Turkish Meteorological Data Archive System), 2010. Düzce and Bolu Meteorological Data. Turkish State Meteorological Service, http://www.dmi.gov.tr/index.aspx. 